\title{
Toll-like receptors 4 and 2 expression in the bronchial mucosa of patients with cystic fibrosis
}

\author{
Hans-Peter Hauber MD ${ }^{1 *}$, Meri K Tulic PhD ${ }^{1 *}$, Anne Tsicopoulos MD², Benoit Wallaert MD², \\ Ron Olivenstein $M D^{1}$, Patrick Daigneault $\mathrm{MD}^{1}$, Qutayba Hamid MD $\mathrm{PhD}^{1}$
}

H-P Hauber, MK Tulic, A Tsicopoulos, et al. Toll-like
receptors 4 and 2 expression in the bronchial mucosa of
patients with cystic fibrosis. Can Respir J 2005;12(1):13-18.

BACKGROUND: Cystic fibrosis (CF) is a lung disease characterized by chronic infection with Gram-negative bacteria Pseudomonas aeruginosa and Gram-positive bacteria Staphylococcus aureus. Recently, toll-like receptor (TLR) 4 has been shown to be responsible for the lipopolysaccharide (LPS)-mediated immune response. While TLR2 mediates responses driven by bacterial lipoproteins and peptidoglycans from Gram-positive bacteria, LPS derived from $P$ aeruginosa may stimulate the immune response in the airways of patients with CF via activation of TLR4.

OBJECTIVES: To investigate TLR4 and TLR2 expression in the bronchial mucosa of patients with CF and normal control subjects.

PATIENTS AND METHODS: Endoscopic bronchial biopsies from seven patients with CF and six healthy control subjects were obtained. TLR4 and TLR2 expression was assessed using immmunocytochemistry. Real-time polymerase chain reaction was used to detect TLR4 messenger RNA in blood cells from patients with CF and to compare TLR4 expression in CF bronchial epithelial cells with non-CF bronchial epithelial cells.

RESULTS: In patients with CF, the number of TLR4-positive cells was significantly increased in their submucosa $(\mathrm{P}<0.05)$ but significantly reduced in their epithelium compared with control subjects $(\mathrm{P}<0.05)$. The majority of TLR4-positive cells were neutrophils. Patients with CF $(n=4)$ and control subjects $(n=4)$ had a similar percentage of TLR4expressing neutrophils and monocytes/lymphocytes in peripheral blood. CF cells (IB-3) had significantly decreased basal TLR4 messenger RNA expression compared with non-CF cells (Calu-3) $(\mathrm{P}<0.05)$. Although there was a trend toward reduced TLR2 expression in the airway epithelium of patients with CF $(\mathrm{P}=0.07)$, there was no significant difference in TLR2 expression in the submucosa of patients with CF compared with that of control subjects.

CONCLUSIONS: Both TLR4 and TLR2 expression in the bronchial epithelium of patients with CF were significantly reduced compared with healthy control subjects. In contrast, the number of TLR4-positive neutrophils in the submucosa of patients with CF was higher than in control subjects. This may suggest that the loss of epithelial TLR expression may contribute to the impaired defense against LPS.

Key Words: Cystic fibrosis; Immunocytochemistry; Neutrophils; TLR2; TLR4
L'expression des récepteurs ressemblant à un péage 4 et 2 dans la muqueuse bronchique de patients atteints de fibrose kystique

HISTORIQUE : La fibrose kystique (FK) est une maladie pulmonaire caractérisée par une infection chronique à la bactérie gram-négative Pseudomonas aeruginosa et à la bactérie gram-positive Staphylococcus aureus. Récemment, il a été démontré que le récepteur ressemblant à un péage (TLR) 4 est responsable de la réponse immunitaire à médiation glucidolipidoprotéique (LPS). Tandis que les TLR2 assurent la médiation des réponses poussées par les lipoprotéines bactériennes et les peptidoglycanes des bactéries gram-positives, des complexes LPS dérivés de $P$ aeruginosa peuvent stimuler la réponse immunitaire dans les voies respiratoires des patients atteints de FK par l'activation du TLR4.

OBJECTIFS : Étudier l'expression du TLR4 et du TLR2 dans la muqueuse bronchique de patients atteints de FK et de sujets témoins en santé.

PATIENTS ET MÉTHODOLOGIE : Des biopsies bronchiques par endoscopie ont été obtenues auprès de sept patients atteints de FK et de six sujets témoins en santé. L'expression du TLR4 et du TLR2 a été évaluée au moyen d'une immunocytochimie. Une réaction en chaîne de la polymérase en temps réel a permis de déceler l'ARN messager du TLR4 dans les globules des patients atteints de FK et de comparer l'expression du TLR4 dans les cellules épithéliales bronchiques de FK à celle des cellules épithéliales bronchiques sans FK.

RÉSULTATS : Chez les patients atteints de FK, le nombre de cellules TLR4-positives était considérablement plus élevé dans la sous-muqueuse $(\mathrm{P}<0,05)$ mais considérablement réduit dans l'épithélium par rapport à celui des sujets témoins $(\mathrm{P}<0,05)$. La majorité des cellules TLR4-positives étaient des neutrophiles. Des patients atteints de FK $(n=4)$ et des sujets témoins $(n=4)$ présentaient un pourcentage similaire de neutrophiles exprimant des TLR4 et de monocytes et lymphocytes dans le sang périphérique. Les cellules de FK (IB-3) présentaient une expression d'ARN messager du TLR4 de base beaucoup moins élevée que les cellules sans FK (Calu-3) $(\mathrm{P}<0,05)$. Bien qu'on ait remarqué une tendance vers une expression réduite du TLR2 dans l'épithélium des voies respiratoires des patients atteints de FK $(\mathrm{P}=0,07)$, on n'a décelé aucune différence marquée de l'expression du TLR2 dans la sous-muqueuse des patients atteints de FK par rapport à celle des sujets témoins.

CONCLUSIONS : L'expression tant du TLR4 que du TLR2 dans l'épithélium bronchique des patients atteints de FK était beaucoup plus faible que celle des sujets témoins en santé. Par contre, le nombre de neutrophiles TLR4-positifs dans la sous-muqueuse des patients atteints de FK était plus élevé que celui des sujets témoins. Ce phénomène pourrait indiquer que la perte de l'expression du TLR épithélial contribue à l'altération de la défense contre le complexe LPS.

\footnotetext{
${ }^{1}$ Meakins-Christie Laboratories, McGill University, Montreal, Quebec; ${ }^{2}$ U416 Institut National de la Santé et de la Recherche Médicale,

Institut Pasteur de Lille and Centre de Soins Mucoviscidose Adulte, Hôpital Calmette, Lille, France

* HPH and MKT contributed equally to this work

Correspondence: Dr Qutayba Hamid, Meakins-Christie Laboratories, McGill University, 3626 St-Urbain Street, Montreal, Quebec H2X 2 P2.

Telephone 514-398-3864, fax 514-398-7483, e-mail qutayba.hamid@mcgill.ca
} 
C ystic fibrosis (CF) is an autosomal recessive disorder caused by mutations in the cystic fibrosis transmembrane conductance regulator (CFTR) gene encoding a chloride channel located in the airway epithelial cells $(1,2)$. Although pathological changes are observed in the pancreas, liver and reproductive tract, the most profound changes occur in the lungs. In the lungs, CF is characterized by mucus overproduction and neutrophil-dominated airway inflammation, which are driven by intense chronic infection with the Gram-negative bacteria Pseudomonas aeruginosa (1,2). These pathological changes destroy the airways, impair gas exchange and are the main cause of mortality among patients with CF. Another important pathogen in CF is the Gram-positive Staphylococcus aureus, which often appears early in the course of CF lung disease (1). Infection with $S$ aureus is also associated with increased neutrophilia and macrophages in bronchoalveolar lavage, as well as with significant elevation of interleukin-8 (3). Currently, the susceptibility of CF airways to S aureus and $P$ aeruginosa is not fully understood.

Recently discovered toll-like receptors (TLRs) are a family of evolutionary conserved receptors that mediate the initial phase of innate immunity via recognition of pathogen-associated molecular patterns. To date, TLRs 1 to 10 have been identified $(4,5)$. TLR2 has been shown to recognize bacterial lipoproteins and peptidoglycan from Gram-positive bacteria, while TLR4 is a receptor for Gram-negative bacterial lipopolysaccharide (LPS) (6-8). In humans, mutations in the TLR4 gene are associated with LPS hyporesponsiveness (9). Because the airways of patients with CF are chronically infected with Grampositive and -negative bacteria, we postulate that TLR2 and TLR4 may play an important role in mediating host-defense responses in these patients.

The expression and role of TLR2 and TLR4 in patients with CF have not been evaluated. Although a recent study (10) has demonstrated TLR2 and TLR4 expression in CF epithelium, the in vitro experiments were performed using CF epithelial cell lines. The expression and regulation of TLRs in vivo in the bronchial mucosa and peripheral blood of patients with CF compared with those of healthy individuals is currently unknown. Furthermore, the phenotype of the cells that express these receptors in patients with $\mathrm{CF}$ remains to be elucidated. Here, we describe, for the first time, a difference in TLR4 and TLR2 expression among patients with CF compared with control subjects, and propose some potential insights into the differential expression and regulation of these receptors in patients with $\mathrm{CF}$.

\section{PATIENTS AND METHODS}

\section{Subjects}

This study was approved by the Montreal Chest Institute (Montreal, Quebec) and the Ethics Committe of the Calmette Hospital (Lille, France). Endoscopic bronchial biopsies were taken from seven patients with CF and six healthy control subjects. Three to four mucosal biopsies from each patient were taken from the subcarinae of the lower lobes or middle lobe of the lung. In addition, blood was taken from a different set of patients with CF $(n=4)$ and control subjects $(n=4)$. Table 1 summarizes the demographics of the two groups. Forced vital capacity and forced expiratory volume in $1 \mathrm{~s}$ were significantly lower in patients with $\mathrm{CF}$ than in control subjects $(\mathrm{P}<0.05)$, reflecting the reduced lung function in patients with CF (Table 1). Sputum cultures showed $S$ aureus in one CF patient and $P$ aeruginosa in six patients with CF. Age and sex distribution between the two groups were similar.
TABLE 1

Clinical characteristics of the total study population

\begin{tabular}{lccc}
\hline & $\begin{array}{c}\text { Patients with CF } \\
(\mathbf{n}=11)^{*}\end{array}$ & $\begin{array}{c}\text { Control subjects } \\
(\mathbf{n}=\mathbf{1 0})^{\dagger}\end{array}$ & $\mathbf{P}$ \\
\hline Mean age (years) & $34.6 \pm 5.1$ & $33.8 \pm 4.6$ & NS \\
Sex (male:female) & $5: 6$ & $7: 3$ & \\
Forced vital capacity (L) & $2.5 \pm 0.2$ & $5.2 \pm 0.2$ & $<0.01$ \\
Forced vital capacity (\%) & $70.9 \pm 5.5$ & $106.3 \pm 5.4$ & $<0.01$ \\
FEV $_{1}(\mathrm{~L})$ & $1.7 \pm 0.1$ & $4.2 \pm 0.2$ & $<0.01$ \\
FEV $_{1}(\%)$ & $56.9 \pm 6.6$ & $104.2 \pm 5.5$ & $<0.01$ \\
\hline
\end{tabular}

*Seven patients with biopsy and four with blood; ${ }^{\dagger}$ Six patients with biopsy and four with blood. Results represented as mean \pm SEM. CF Cystic fibrosis; $F E V_{1}$ Forced expiratory volume in $1 \mathrm{~s}$; NS Not significant

\section{Tissue and blood sample preparation}

Three to four mucosal biopsies were obtained from the subcarinae of the lower lobes or middle lobe of each patient. All biopsy specimens were fixed with $4 \%$ paraformaldehyde, blocked in optimal cutting temperature medium and snap frozen in liquid nitrogen-cooled isopentane. Sections ( $5 \mu \mathrm{m}$ to $10 \mu \mathrm{m}$ thick) were mounted on polyL-lysine $(0.1 \%)$-coated glass slides and baked overnight at $37^{\circ} \mathrm{C}$. Peripheral blood was diluted (1:1) with sterile phosphate buffer solution (PBS) and centrifugated over Ficoll Paque (Amersham Biosciences, Sweden). The interphase, containing mononuclear cells, was removed and washed twice with PBS to obtain peripheral blood mononuclear cells (PBMs). To isolate polymorphonuclear cells (PMNs), the phase containing PMNs and red blood cells was mixed with $10 \%$ dextran (Sigma-Aldrich, USA). After a $30 \mathrm{~min}$ incubation at room temperature, the supernatant was removed, and the remaining interphase was diluted with PBS (1:1) and centrifugated at $1600 \mathrm{rpm}$ for $10 \mathrm{~min}$. The supernatant was discarded and the cell pellet was resuspended in hypotonic $\mathrm{NaCl}$ solution $(0.2 \%)$ to lyse the remaining red blood cells. Hypertonic $\mathrm{NaCl}$ solution (1.6\%) was then added to restore normotonic osmolarity. After a second centrifugation, the supernatant was discarded and the cell pellet containing PMNs was resuspended in PBS. Routinely, neutrophils made up more than $90 \%$ of PMNs. PMN cytospins were prepared $(100,000$ cells/slide $)$, and the slides were fixed in an acetone:methanol solution (60:40).

\section{Immunocytochemistry}

TLR2 and TLR4 immunoreactivity was assessed by alkaline phosphatase antialkaline phosphatase immunocytochemistry as previously described (11), using polyclonal primary antibodies against TLR2 (goat antihuman TLR2, 1:200; Santa Cruz Biotechnology, USA) or against TLR4 (rabbit antihuman TLR4, 1:10; Santa Cruz Biotechnology). Briefly, after applying blocking solution (DAKO Protein Block; DAKO, Denmark) to prevent nonspecific binding, the sections were incubated with primary antibody overnight at $4^{\circ} \mathrm{C}$. The next day, the slides were incubated with the secondary antibody for $30 \mathrm{~min}$ (rabbit antigoat-immunoglobulin biotin for TLR2 or swine antirabbit-immunoglobulin biotin for TLR4), washed and tertiary antibody (Streptavidin-AP; Dako, Denmark) was added for a further $30 \mathrm{~min}$. Immunostaining was developed with Fast Red (Sigma Chemicals, Canada). All slides were counterstained with Gill II hematoxylin (Dako, Denmark). Positive cells appeared red under bright field illumination. For negative controls, the primary antibody was replaced by an isotype-matched control antibody.

Double alkaline phosphatase antialkaline phosphatase immunocytochemistry was used to examine whether neutrophils or macrophages expressed TLR4 in the bronchial mucosa. Briefly, slides were incubated overnight at $4^{\circ} \mathrm{C}$ with a mixture of primary 
monoclonal antibody directed against elastase (1:100) or CD68 (1:50) (mouse antihuman, DAKO) with polyclonal antibody directed against TLR4 (1:10). Secondary and tertiary antibodies were applied at different incubation periods, each for $30 \mathrm{~min}$ at room temperature. Immunostaining was developed with Fast Red (Sigma Chemicals), and all slides were counterstained with Gill II hematoxylin (Dako). Elastase- or CD68-positive cells appeared red, and elastase/TLR4 or CD68/TLR4 double positive cells appeared as redbrown immunostaining. Immunocytochemistry was also performed on isolated neutrophils and PBMs from the peripheral blood smears of patients with CF and control subjects to examine TLR4 expression.

\section{Quantification}

All cells in individual biopsy specimens were counted by two observers, who were blinded to the conditions, using an Olympus light microscope (Carson Group Inc, Canada) at $\times 200$ magnification with an eyepiece graticule of $0.202 \mathrm{~mm}^{2}$. At least two sections were counted for each subject, and the counts were averaged. In each section, the number of positive cells was averaged from six to eight random, nonoverlapping grids and expressed as the mean number of positive cells per field. Individual cells in the submucosa were identified by the presence of a nucleus. Only cells that stained red and whose nucleus could be identified were counted as positive cells. The columnar and basal epithelial cells were identified by the presence of dark nuclei sitting in the intact epithelium above the basement membrane. An intact epithelium was an epithelium that did not have epithelial desquamation or loss of epithelial cells (ie, the cell had basal epithelial cells attached at the basement membrane). TLR immunoreactivity in the epithelium was semiquantified by measuring the length of the epithelium that stained positive for TLR4 or TLR2, and was expressed as a percentage of the total length of the intact epithelium in a given biopsy section. TLR4 immunoreactivity in PMN and PBM cytospin preparations was determined by counting the number of TLR4-positive cells out of a total of 400 cells counted in random, nonoverlapping fields, and was expressed as the percentage of total cells.

\section{Cell culture}

CFTR-deficient bronchial epithelial cells (IB-3) were cultured in light harvesting complex-9 medium (Medicorp, Canada). Mucusproducing bronchial epithelial cells expressing CFTR (Calu-3) were cultured in Eagle's minimum essential medium (Invitrogen, USA) supplemented with $10 \%$ fetal calf serum. Cell passages 3 to 5 were used for experiments. Total RNA was extracted from epithelial cells (80\% to $90 \%$ confluent) using the Qiagen RNeasy kit (Qiagen, USA) and TLR4 messenger RNA (mRNA) was measured using reverse transcription polymerase chain reaction (PCR).

\section{Reverse transcription and real-time PCR for detection of TLR4 mRNA}

RNA from IB-3 and Calu-3 cells was extracted using an RNeasy Mini Kit (Qiagen). RNA from PBM and PMN lysates ( $n=4)$ was extracted with TRIzol (Invitrogen, USA) and chloroform (greater than 99\%, Sigma-Aldrich), and precipitated with isopropanol (greater than 99\%, Sigma-Aldrich). The resultant mRNA was reverse transcribed into complemetary DNA. Real-time PCR, using a LightCycler system (Roche Diagnostics, USA) and QuantiTect SYBR Green PCR Kit (Qiagen), was performed to detect TLR4 mRNA expression. TLR4 primers used in the present study were designed based on the previously published TLR4 mRNA sequence (12). ALAS-1 was used as a housekeeping gene for the quantification of TLR4 expression in IB-3 and Calu-3 cells. All PCR experiments were carried out in triplicate.

\section{Statistical analysis}

The difference in the number of TLR2 or TLR4 immunoreactive cells and the difference in the percentage of epithelium positive for TLR2/TLR4 between CF patients and normal control subjects was compared using ANOVA with Dunnett post hoc analysis for multiple comparisons (Systat, version 10; SyStat Inc, USA). To compare TLR4 expression in IB-3 and Calu-3 cells, ratios of TLR4 expression to ALAS-1 expression were calculated. The means of three experiments were calculated to compare TLR4 expression in IB-3 and Calu-3 cells. All results are expressed as mean \pm SEM. $\mathrm{P}<0.05$ was considered statistically significant.

\section{RESULTS}

\section{TLR2 and TLR4 expression in bronchial mucosa}

TLR2 - and TLR4-positive cells were expressed in the submucosa (Figure 1A) and airway epithelium (Figure 1B) of both CF and control subjects. TLR4 expression was significantly higher than TLR2 expression in the submucosa and epithelium of CF patients and control subjects (Figure 1) $(\mathrm{P}<0.05)$. Figure 2 is a representative example of TLR2 and TLR4 expression in a control subject and a patient with CF. TLR2 expression in the epithelium and the submucosa was low in control subjects and patients with CF (Figure 2A and B). TLR4 immunoreactivity was low in the airway epithelium, but strong in the submucosa of patients with CF (Figure 2D) compared with control subjects (Figure 2C). The number of TLR4-positive cells in CF submucosa $(14.67 \pm 3.61$ cells/field $)$ was almost threefold higher than in the submucosa of control subjects $(5.80 \pm 2.84$ cells/field $)$ $(\mathrm{P}<0.05)$ (Figure 1A). The number of TLR2-positive cells in CF submucosa $(0.86 \pm 0.26$ cells/field $)$ was similar to that observed in the submucosa of control subjects $(1.20 \pm 0.37$ cells/field) (Figure 1A). In the airway epithelium, TLR4 expression was significantly lower in patients with CF $(28.57 \pm 10.10 \%)$ than in control subjects $(62.50 \pm 7.22 \%) \quad(\mathrm{P}<0.05) \quad$ (Figure $1 \mathrm{~B})$. Although not significant, there was a trend toward increased TLR2 expression in the airway epithelium of control subjects compared with patients with CF $(7.14 \pm 4.61 \%$ versus $30.00 \pm 12.25 \%$, respectively; $\mathrm{P}=0.07$ ) (Figure $1 \mathrm{~B}$ ).

\section{Source of TLR4 in CF submucosa}

As expected, the number of elastase-positive neutrophils in $\mathrm{CF}$ mucosa $(9.1 \pm 2.4$ cells/field $)$ was significantly higher than in control subjects $(4.9 \pm 1.1$ cells/field $)(\mathrm{P}<0.05)$. There was no significant difference in the number of CD68-positive monocytes/macrophages between CF patients and healthy control subjects (3.6 \pm 0.9 cells/field versus $4.5 \pm 1.3$ cells/field, respectively). The number of TLR4-positive, elastase-positive cells was significantly higher in CF patients than in control subjects $(6.1 \pm 1.3$ cells/field versus $3.3 \pm 0.9$ cells/field $)(\mathrm{P}<0.05)$. In contrast, there was no significant difference in the number of TLR4-positive, CD68-positive cells between the two groups (CF: $1.9 \pm 0.6$ cells/field versus control subjects: $2.8 \pm 0.9$ cells/field) (Figure 3 ).

In patients with CF, $64 \pm 6 \%$ of all TLR 4 immunoreactive cells were elastase-positive neutrophils and $32 \pm 12 \%$ were CD68positive monocytes/macrophages; in the control group, only $50 \pm 4 \%$ of all TLR 4 -positive cells were elastase-positive neutrophils and $45 \pm 12 \%$ were CD68-positive monocytes/macrophages. The percentage of TLR4-positive cells that were also elastase-positive was significantly higher in CF patients than in control subjects $(\mathrm{P}<0.05)$. No significant difference was found in the percentages of TLR4-positive, CD68-positive cells between the groups. Figure 4A shows an example of TLR4-positive, elastase-positive immunopositive cells in the bronchial mucosa of a patient with 


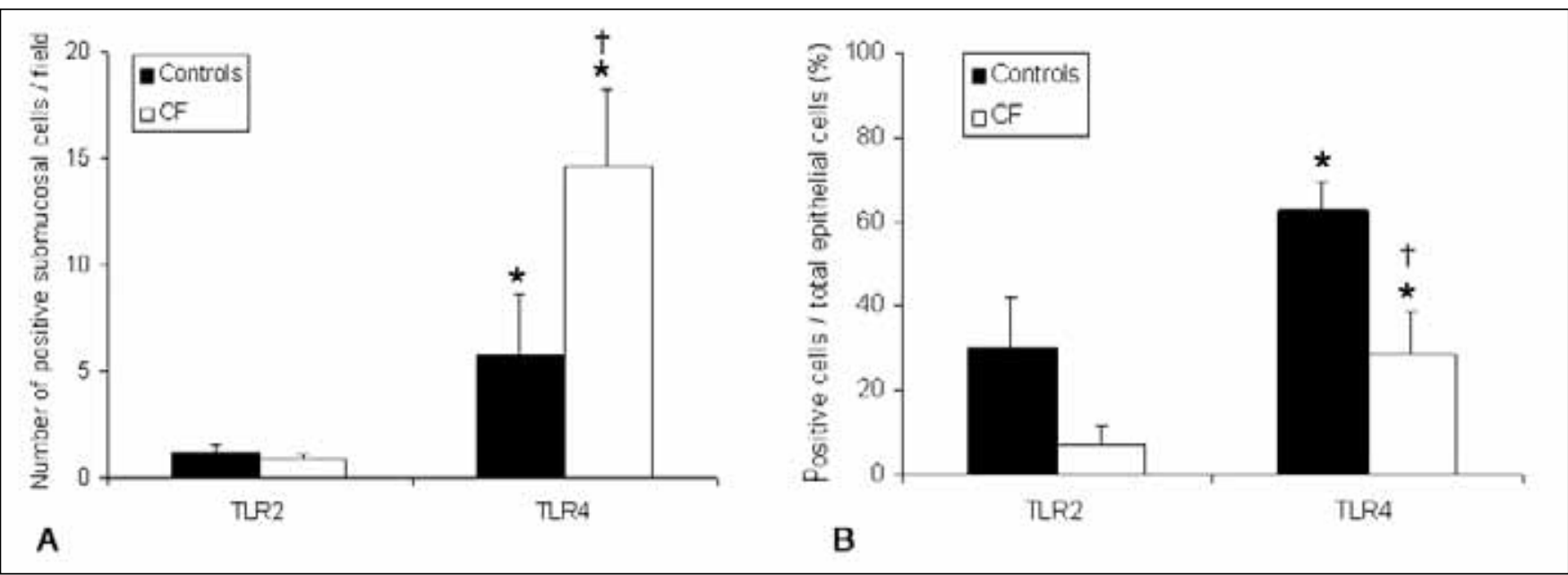

Figure 1) Toll-like receptor (TLR) 2 and TLR4 expression in the (A) submucosa and (B) airway epithelium of patients with cystic fibrosis $(\mathrm{CF} ; n=7)$ and of control subjects (controls; $n=6)$. Results are represented as the number of TLR2 or TLR4 immunopositive cells per field and are expressed as mean \pm SEM. $* P<0.05$ versus the TLR2 group.; ${ }^{\dagger} \mathrm{P}<0.05$ versus the control group

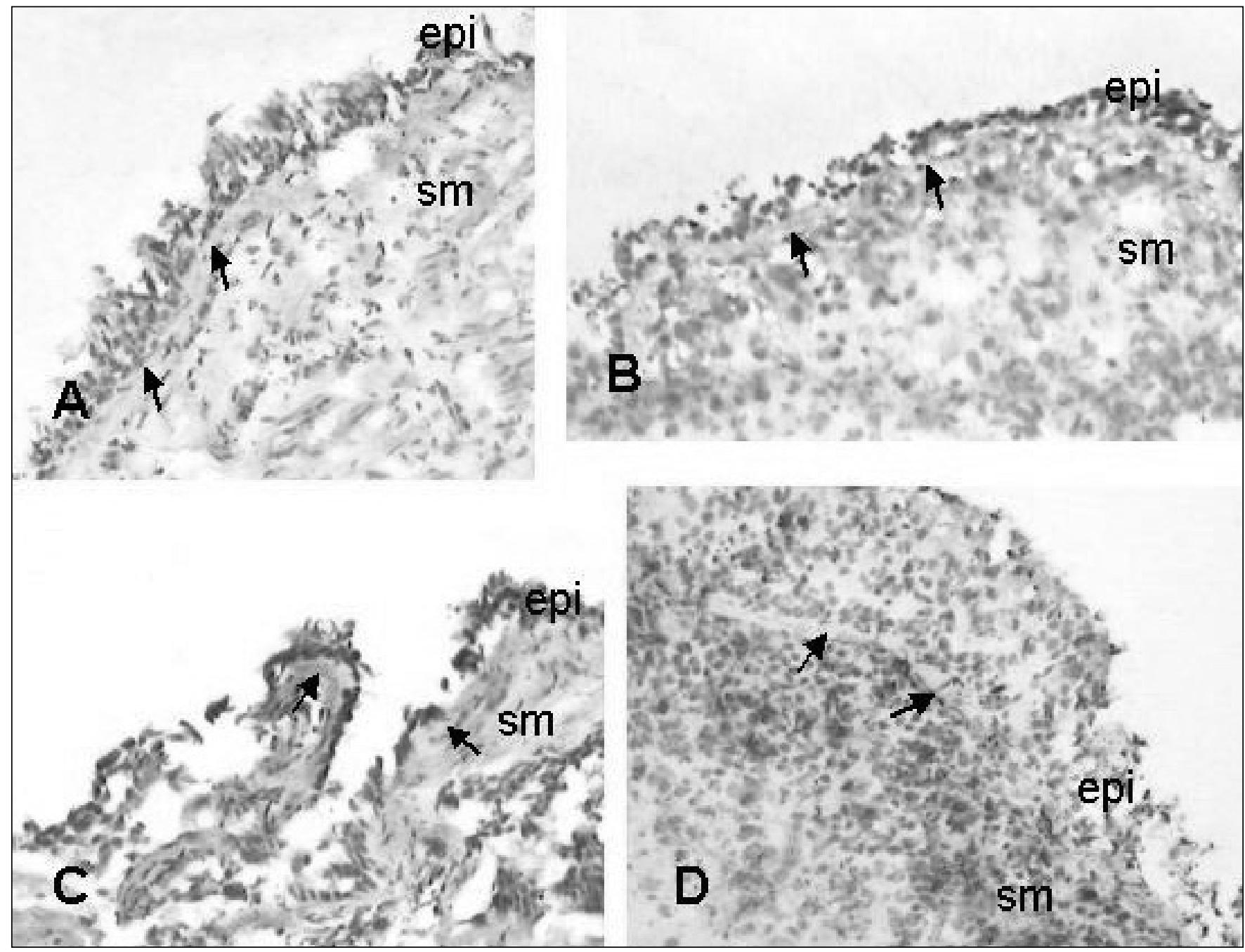

Figure 2) Representative examples of toll-like receptor (TLR) 2 (A and B) and TLR4 (C and D) immunostaining in the bronchial mucosa of a control subject ( $\mathbf{A}$ and $\mathbf{C}$ ) and a patient with cystic fibrosis (CF) (B and $\mathbf{D})$. TLR2 expression is weak in both the control subject (A) and the patient with CF (B). While there was a greater number of TLR4-positive cells in the epithelium (epi) of the control subject (C) than of the patient with CF (D), there was a greater number of TLR4-positive cells in the submucosa (sm) of the patient with CF than of the healthy control. Original magnification $\times 200$. Arrows point to the basal membrane 


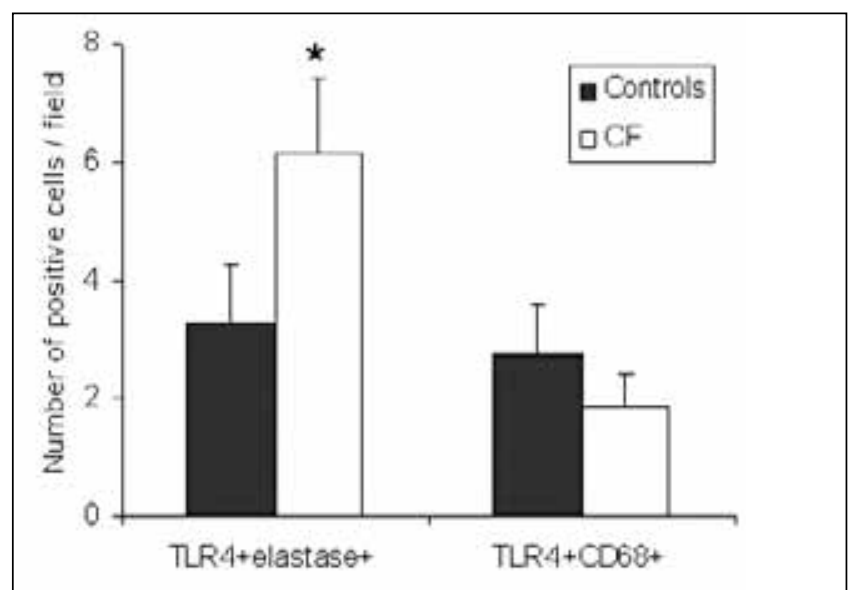

Figure 3) Double immunopositive (toll-like receptor 4-positive [TLR4+] and elastase-positive [elastase+] or TLR4+ and CD68-positive [CD68+]) cells in control subjects (controls; $n=6$ ) and in patients with cystic fibrosis (CF; $n=7$ ). Results are shown as the number of double positive cells per field, and are expressed as mean \pm SEM. $* P<0.05$ versus the control group

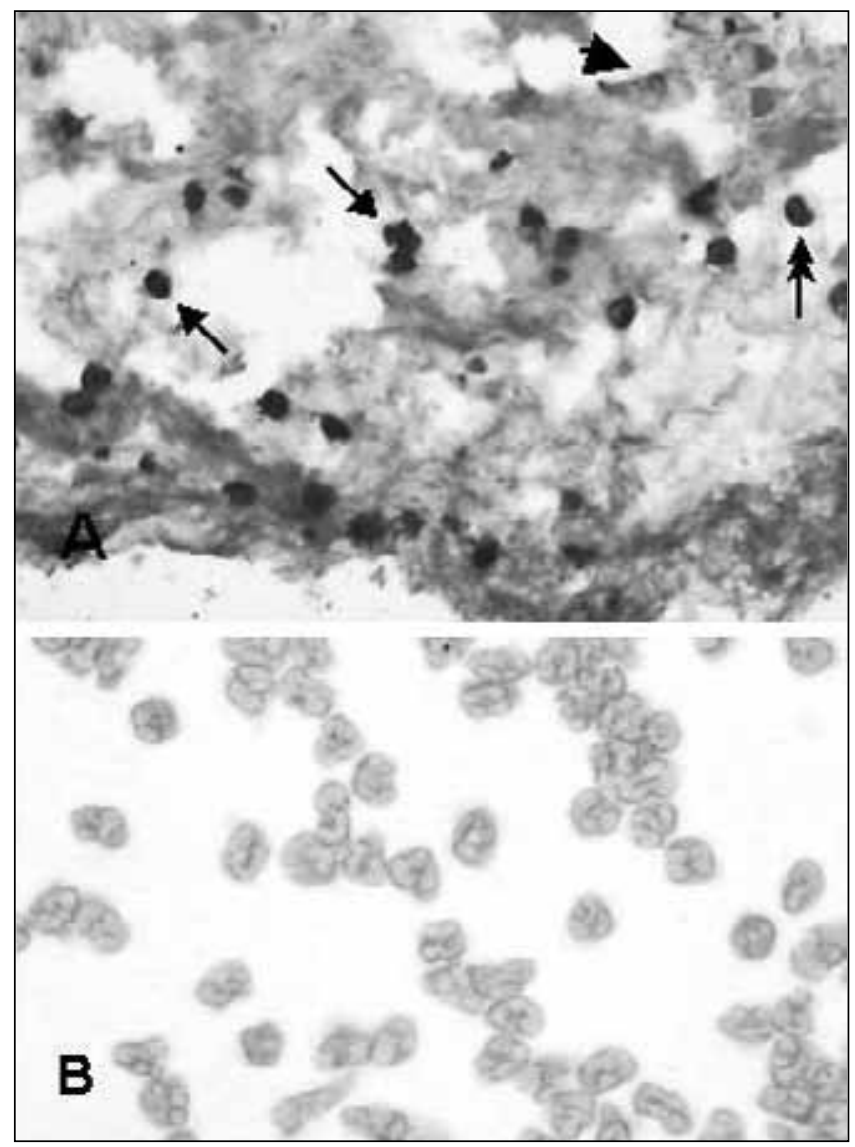

Figure 4) A Double immunocytochemistry illustrating toll-like receptor (TLR) 4-positive cells (double arrow) colocalized (arrows) with elastase-positive neutrophils (arrowhead) in the bronchial mucosa of a patient with cystic fibrosis (CF). Most of the submucosal cells stained double positive. Original magnification $\times 400$. Arrows illustrate TLR4-positive, elastase-positive cells; double arrowhead points to TLR4-positive, elastase-negative cell; single arrow head shows TLR4-negative, elastase-positive cell. B TLR4positive cells in polymorphonuclear cells (neutrophils) of a patient with CF. TLR4 was expressed by the majority of the cells

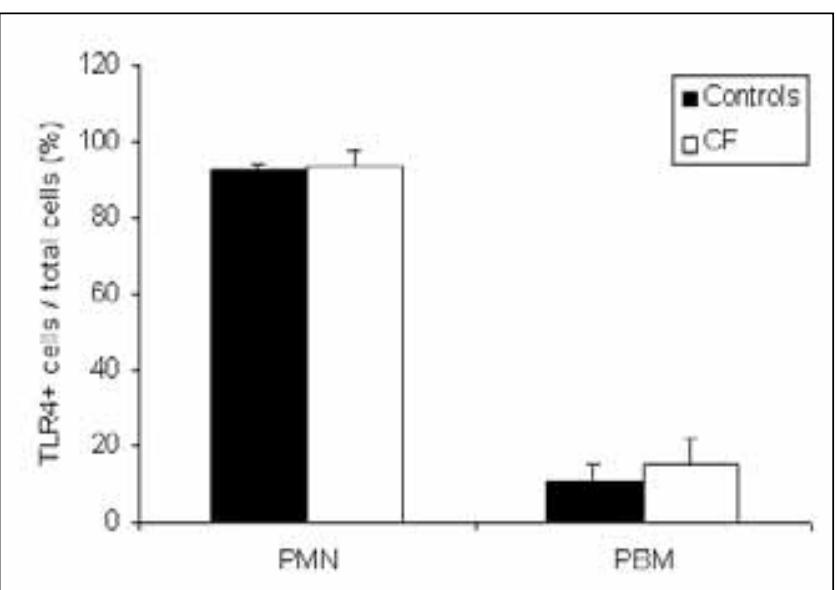

Figure 5) The percentages of toll-like receptor (TLR) 4-positive polymorphonuclear cells (PMN) and TLR4-positive peripheral blood mononuclear cells (PBM) isolated from the peripheral blood of control subjects (controls; $n=4)$ and patients with cystic fibrosis $(C F ; n=4)$. Results are expressed as the mean percentage \pm SEM

CF. Greater than $60 \%$ of all elastase-positive cells in patients with CF expressed TLR4 (Figure 4A).

TLR4 expression in blood cells

TLR4 mRNA was detected in both PBM (monocytes and lymphocytes) and PMN (neutrophils) lysates from patients with CF. Immunocytochemistry showed positive staining for TLR4 in both CF and control PMN lysates, but the percentage of TLR4-positive cells was similar between the two groups $(93.9 \pm 3.6 \%$ versus $92.4 \pm 1.9 \%$, respectively). Figure 4B shows an example of TLR4 immunodetection in PMN from a patient with CF in which almost all of the PMNs express TLR4 protein. Positive TLR4 immunostaining was also detected in PBMs from both CF patients and control subjects; however, the percentage of immuno-positive cells was significantly lower than was observed in the PMNs (Figure 5).

\section{TLR4 mRNA expression in CF and non-CF bronchial epithelial cells}

The constitutive expression of TLR4 mRNA was almost fivefold higher in control bronchial epithelial cells (Calu-3) $\left(2.24 \pm 1.79 \times 10^{-4}\right.$; ratio of TLR4:ALAS-1) than in CF bronchial epithelial cells $(\mathrm{IB}-3)\left(4.51 \pm 3.53 \times 10^{-5}\right)(\mathrm{P}<0.05)$ (Figure 6).

\section{DISCUSSION}

Chronic infection of the lungs with Gram-negative $P$ aeruginosa and Gram-positive $S$ aureus leads to chronic inflammation and destruction of lung parenchyma, and is the most important cause of morbidity and mortality in patients with CF $(1,2)$. The underlying mechanisms involved in the pathogenesis of CF have not been fully elucidated. Because TLR2 and TLR4 are critical in mediating Gram-negative- and Gram-positive-induced cell signalling, respectively, we investigated their expression and regulation in normal and CF airways. In the present study, we have demonstrated an increased number of TLR4 immunoreactive cells in the submucosa and decreased expression of TLR4 in the bronchial epithelium of CF bronchial biopsies compared with those from control subjects. Neutrophils accounted for almost $65 \%$ of total TLR4-positive inflammatory cells present in the lungs of patients with CF. A trend toward decreased TLR2 expression was seen in CF bronchial epithelium but not in $\mathrm{CF}$ 


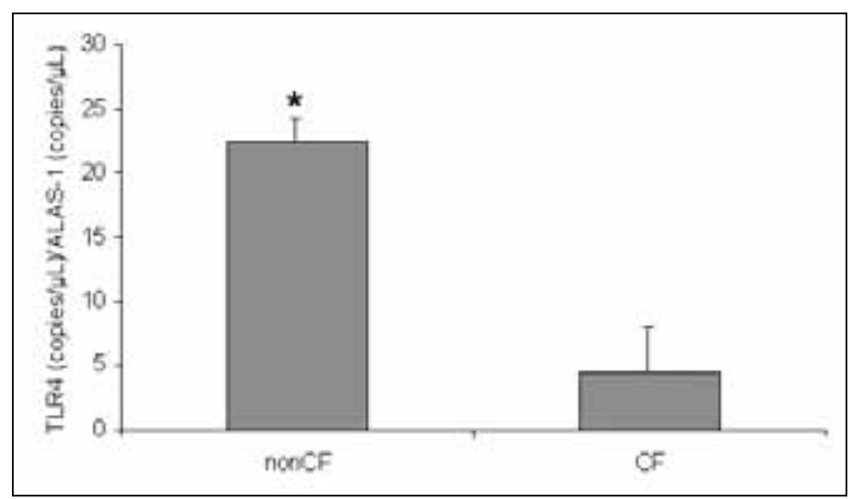

Figure 6) Toll-like receptor (TLR) 4 messenger RNA expression in noncystic fibrosis (CF) (Calu-3) and CF (IB-3) epithelial cell lines. Columns represent mean \pm SEM. $* \mathrm{P}<0.05$ versus $\mathrm{CF}$ cells

submucosa compared with control subjects. To our knowledge, this is the first study to show in vivo expression of TLR4 and TLR2 in the bronchial mucosa of CF airways.

The reasons for reduced TLR4 (and TLR2) expression in CF airway epithelium is not completely understood; however, recent results by Devaney et al (13) suggested that neutrophil elastase is responsible for downregulating TLR4 protein expression in human bronchial epithelial cells. Neutrophil elastase is a potent protease, produced largely by neutrophils in the lungs of patients with CF, and has been shown to be involved in the degradation and destruction of components of the lung matrix. Another possible explanation is that the lack of CFTR function in CF contributes to decreased TLR4 expression. Our experiments comparing TLR4 mRNA expression in CF bronchial epithelial cells (IB-3) with non-CF bronchial epithelial cells (Calu-3) showed significantly reduced baseline expression of TLR4 mRNA in IB-3 cells, suggesting that a lack (or malfunction) of CFTR may be responsible for reduced TLR4 expression.

Reduced epithelial TLR4 expression may cause the loss of a primary defense mechanism in innate immunity, thereby, facilitating chronic infection with Gram-negative bacteria. The decreased TLR2 expression in CF epithelial cells may contribute to impaired innate defense mechanisms against Gram-positive bacteria. We may speculate that the increased number of TLR4expressing cells in the submucosa of CF airways may represent a second line of defense that provides inflammatory cells to deal with Gram-negative bacteria, such as P aeruginosa, which is commonly found in CF lungs. More than $60 \%$ of TLR4-expressing cells in patients with CF were neutrophils, whereas in control subjects, neutrophils made up only one-half of all TLR4-positive cells. Although the percentage of TLR4-positive neutrophils was similar between patients with CF and control subjects, the absolute number of neutrophils in patients with CF was significantly higher than in controls. Furthermore, the absolute number of TLR4-positive, elastase-positive cells was significantly higher in CF bronchial mucosa than in control mucosa. These findings suggest that TLR4-positive neutrophils play an important role in the fight against $P$ aeruginosa. On the other hand, more CD68positive monocytes/macrophages expressed TLR4 in control subjects than in patients with CF. Although this difference was not significant, it seems that in healthy subjects, TLR4 is mainly expressed by monocytic cells, whereas in patients with CF, the infiltrating neutrophils are the major source of TLR4.

In the peripheral blood, no significant difference in the percentage of TLR4-positive neutrophils or TLR4-positive monocytes/lymphocytes between CF patients and control subjects was observed. This was not a surprising result because although inflammation in CF occurs in multiple organs, the damage is the most severe in the lungs. However, it has to be taken into account that the absolute number of peripheral neutrophils was generally higher in patients with CF than in healthy control subjects.

We do acknowledge that there was an unequal ratio of men to women in the two study groups, and although it has been previously reported (14) that sex can have an influence on the response to inhaled LPS, comparative analysis of TLR4 (and TLR2) expression within groups did not reveal any significant differences between male and female subjects in the TLR4 expression levels.

In the present study, patients with CF were compared with normal control subjects. It would have been very interesting to compare patients with CF to patients with bronchiectasis because these patients often suffer from infection from $P$ aeruginosa; however, bronchial biopsies from these patients are extremely hard to obtain. We are aware that the current study is largely descriptive; nevertheless, these findings provide a new direction toward understanding the persistance of chronic inflammation with $P$ aeruginosa in CF lungs. Ongoing experiments will examine TLR4 and TLR2 expression in CFTRexpressing epithelial cells compared with epithelial cells without CFTR and investigate the effect of LPS stimulation. Furthermore, the role of cytokines on TLR4 and TLR2 expression in epithelial cells warrants thorough investigation. Understanding the role of TLR2 and TLR4 in CF pulmonary disease will clearly have an impact on therapeutic strategies that aim to eradicate infection in these patients.

ACKNOWLEDGEMENTS: The authors thank the Canadian Institutes of Health Research (CIHR) and JT Costello Memorial Research Fund. Drs H-P Hauber and MK Tulic were recipients of the GlaxoSmithKline/Canadian Lung Association/CIHR Fellowships. Dr Q Hamid was a recipient of the Senior Fonds de la recherche en santé du Québec Chercheur-Boursier Award.

SUPPORT: This study was supported by the Canadian Institutes of Health Research and the Christiane-Herzog-Stiftung.

\section{REFERENCES}

1. Davis PB, Drumm M, Konstan MW. Cystic fibrosis. Am J Respir Crit Care Med 1996;154:1229-56.

2. Ratjen F, Doering G. Cystic fibrosis. Lancet 2003;361:681-9.

3. Armstrong DS, Grimwood K, Carzino R, Carlin JB, Olinsky A, Phelan PD. Lower respiratory tract infection and inflammation in infants with newly diagnosed cystic fibrosis. BMJ 1995;310:1571-2.

4. Muzio M, Polentarutti N, Bosisio D, Prahladan MK, Mantovani A. Toll-like receptors: A growing family of immune receptors that are differentially expressed and regulated by different leukocytes. J Leukoc Biol 2000;67:450-6.

5. Schuster JM, Nelson PS. Toll receptors: An expanding role in our understanding of human disease. J Leukoc Biol 2000;67:767-73.

6. Poltorak A, He X, Smirnova I, et al. Defective LPS signaling in $\mathrm{C} 3 \mathrm{H} / \mathrm{HeJ}$ and C57BL/10ScCr mice: Mutations in Tlr4 gene. Science 1998;282:2085-8.

7. Qureshi ST, Lariviere L, Leveque G, et al. Endotoxin-tolerant mice have mutations in Toll-like receptor 4 (Tlr4). J Exp Med 1999;189:615-25. Erratum in: $1999 ; 189: 1518$.

8. Chow JC, Young DW, Golenbock DT, Christ WJ, Gusovsky F. Toll-like receptor-4 mediates lipopolysaccharide-induced signal transduction. J Biol Chem 1999;274:10689-92

9. Arbour NC, Lorenz E, Schutte BC, et al. TLR4 mutations are associated with endotoxin hyporesponsiveness in humans. Nat Genet2000;25:187-91.

10. Muir A, Soong G, Sokol S, et al. Toll-like receptors in normal and cystic fibrosis airway epithelial cells. Am J Respir Cell Mol Biol 2004;30:777-83.

11. Hamid Q, Springall DR, Riveros-Moreno V, et al. Induction of nitric oxide synthase in asthma. Lancet 1993;342:1510-3.

12. Gen Bank, National Center for Biotechnology Information. Accession code NM_003266. <http://www.ncbi.nlm.nih.gov/entrez/viewer.fcgi?db= nucleotide\&val $=19924147>($ Version current at October 28, 2004)

13. Devaney JM, Greene CM, Taggart CC, Carroll TP, O’Neill SJ, McElvaney NG. Neutrophil elastase up-regulates interleukin-8 via toll-like receptor 4. FEBS Lett 2003;544:129-32.

14. Kline JN, Cowden JD, Hunninghake GW, et al. Variable airway responsiveness to inhaled lipopolysaccharide. Am J Respir Crit Care Med 1999;160:297-303. 


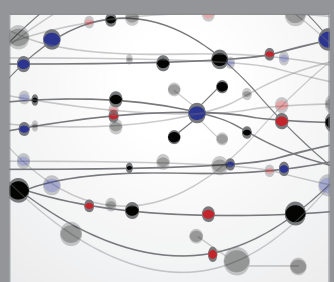

The Scientific World Journal
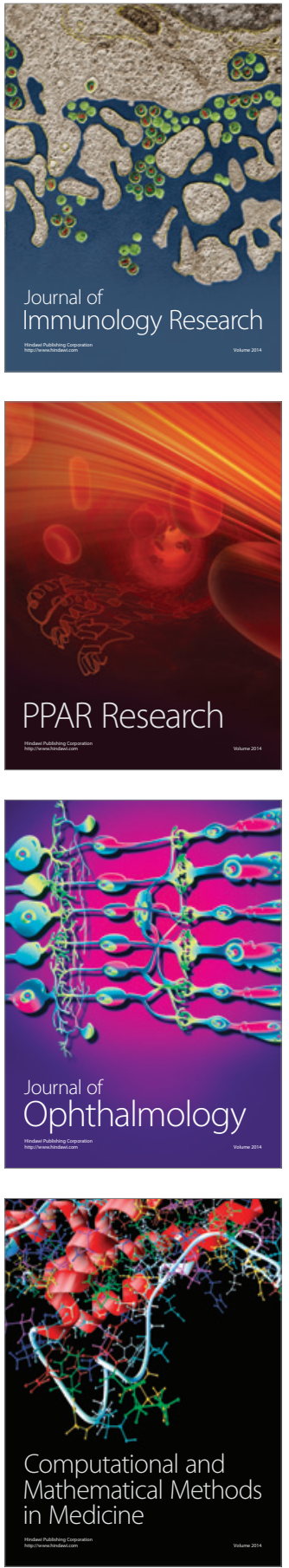

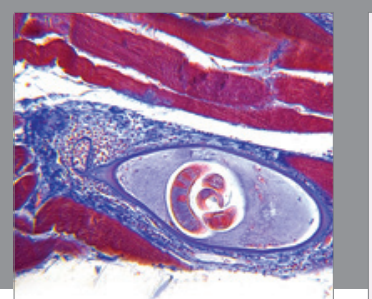

Gastroenterology Research and Practice

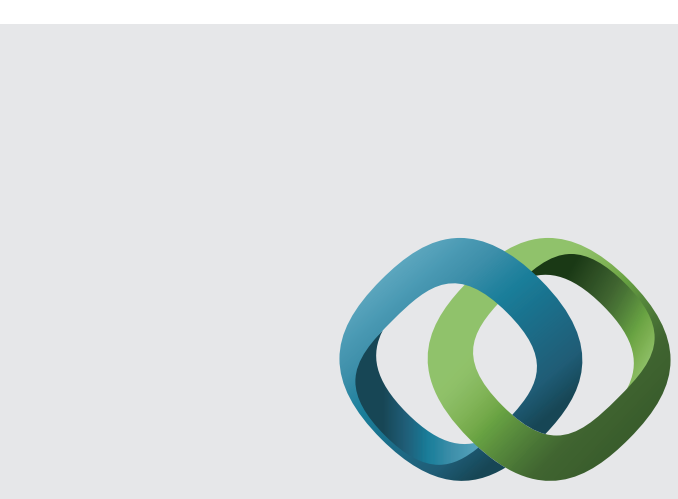

\section{Hindawi}

Submit your manuscripts at

http://www.hindawi.com
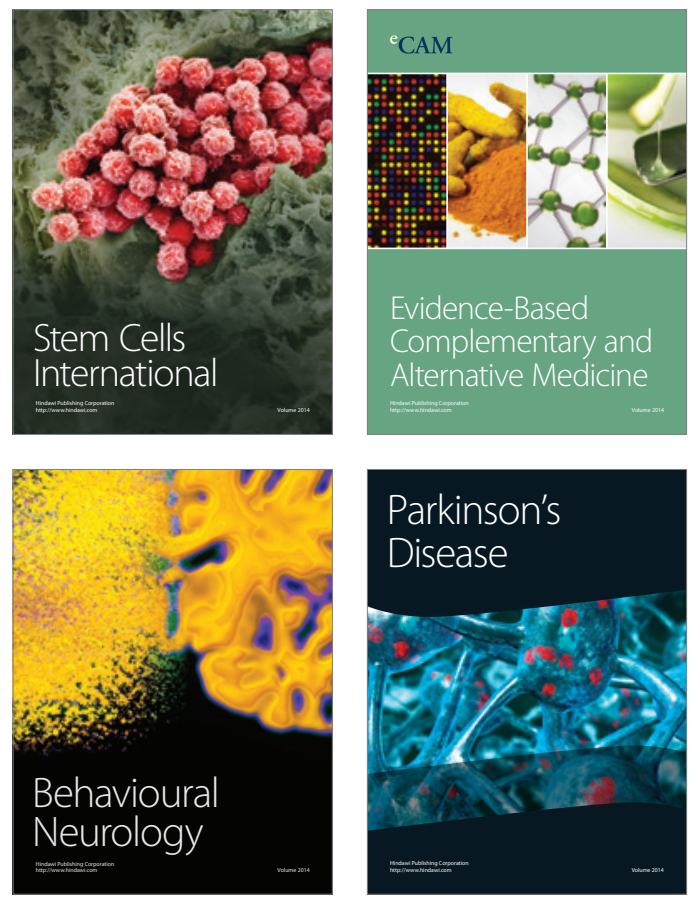
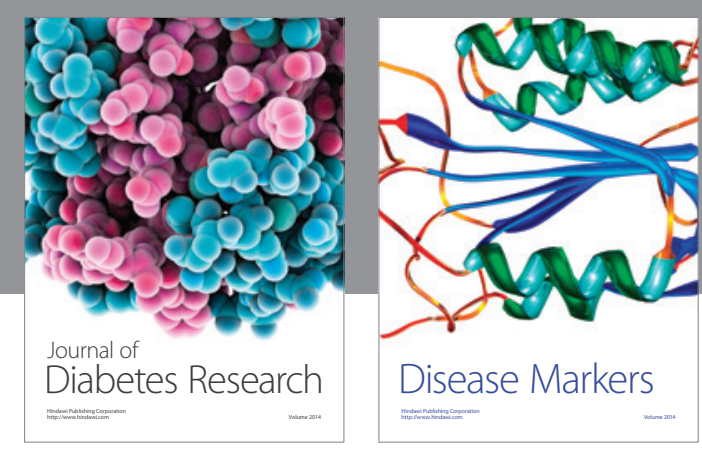

Disease Markers
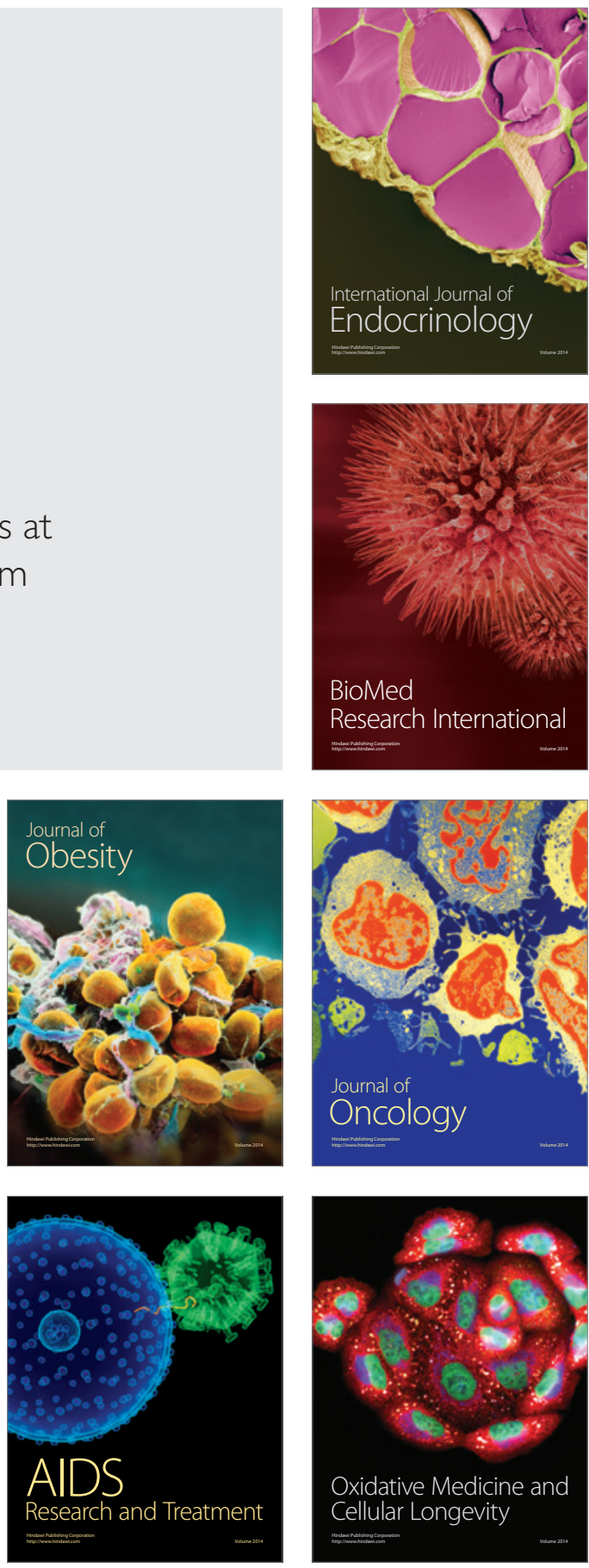